\title{
GC-MS Analysis and Antioxidant Activity of Spondias purpurea L (Anacardiaceae)
}

\author{
Taiwo Olayemi Elufioye*, Tomayo Ireti Berida
}

\section{Taiwo Olayemi Elufioye*, Tomayo Ireti Berida}

Department of Pharmacognosy, Faculty of Pharmacy, University of Ibadan, NIGERIA.

\section{Correspondence}

\section{Taiwo Olayemi Elufioye}

Department of Pharmacognosy, Faculty of Pharmacy, University of Ibadan, NIGERIA.

\section{Phone no : +234 8033850773}

E-mail: toonitaiwo@yahoo.com

\section{History}

- Submission Date: 05-03-2018;

- Review completed: 03-05-2018;

- Accepted Date: 22-06-2018

\section{DOI : 10.5530/pj.2018.5.159}

Article Available online http://www.phcogj.com/v10/i5

\section{Copyright}

(C) 2018 Phcog.Net. This is an openaccess article distributed under the terms of the Creative Commons Attribution 4.0 International license.

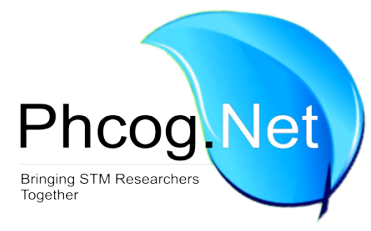

\begin{abstract}
Background: There are ongoing efforts to identify the chemical composition of plants used as food or medicines in other to correlate their components with the numerous claims of their medicinal usefulness in folklore. Objective: This work is aimed at profiling the phytochemical composition of Spondias purpurea using GC-MS, as well as to determine the total phenolic content, total flavonoid content and the antioxidant capacity by DPPH radical scavenging assay. Methods: Whole fruit and stem bark of Spondias purpurea were collected, dried, extracted with methanol and concentrated in vacou before assessing them for their total phenolic content by Folin-Ciocalteu's phenol reagent method; total flavonoid content and 2, 2-diphenyl-1-picrylhydrazyl (DPPH) free radical scavenging activities. The whole fruit and stem bark extracts were partitioned into n-hexane, dichloromethane, ethyl acetate and aqueous fractions. The n-hexane fraction of the stem bark and whole fruit were analyzed on GC-MS. Results: The stem bark had the highest phenolic content of 29.81 $1.18 \mathrm{GAE} \mathrm{mg} / \mathrm{g}$. Similarly, free radical scavenging activities assay showed the stem bark to be most active with $I C_{5}$ of $6.20 \pm 1.51 \mu \mathrm{g} / \mathrm{ml}$, better than the standard, ascorbic acid with $\mathrm{IC}_{50}$ of $11.51 \pm 0.3 \mu \mathrm{g} / \mathrm{ml}$. The $\mathrm{n}$-hexane partitioned fractions of the fruit and stem bark on GC-MS analysis showed 9 prominent compounds including 9,17-Octadecadienal (5.43\%), 3-((4Z,7Z)-Heptadeca-4,7-dien-1-yl) phenol(12\%), (Z)-3-(Heptadec-10-en-1-yl) phenol (11.76\%), n-Hexadecanoic acid $(7.07 \%)$ and 13 compounds including 9,17-Octadecadienal (20.51\%), trans-13-Octadecenoic acid (12.61\%), Pentadecanoic acid (8.3\%), n-Hexadecanoic acid(15.24\%). Conclusions: This study provides justification for some of the folkloric use of Spondias purpurea.

Key words: GC-MS, Spondias purpurea, Total Phenols, Total flavonoids, Antioxidant activity, $\mathrm{DPPH}$.
\end{abstract}

\section{INTRODUCTION}

Traditional medicine has remains a vital alternative source of medicine world over especially in low income countries. It has been reported that $80 \%$ of the world population (about 4 billion people) are dependent primarily on herbal remedies and traditional medicinal practice for their health care. ${ }^{1}$ The increasing incidence of resistance (especially to antibiotics), undesirable side effects, cost of available therapies and the better understanding of disease states has led to a renewed interest in the development of newer molecules from natural sources. ${ }^{2}$ Consequently, aggressive screening of plants used in traditional medicine as well as attempt to identify and undertake chemical elucidation of the compounds responsible for their reported activities are been undertaken by scientists.

Spondias purpurea L. is a flowering plant in the Anacardiaceae family. It is indigenous to tropical South America but has now been naturalized in countries like Nigeria and Philippines. ${ }^{3-5}$ The plant produces an oval, aromatic, smooth and often glossy fruits valued for it food. ${ }^{6}$ In Nigeria, the plant is grown in the northern part of the country where it is referred to as Iyeye by the Okuns, Osinkara by the Ebira and Jinjere by the Nupe people. Report on this plant is scares in Nigeria and most studies on it are of South American origin. S. purpurea has been used to treat various diseases such as gastric disorders, diabetes and cholesterol disorder, skin infections and anemia in various traditional medicine systems. ${ }^{7-8}$ In Mexico, the fruits are considered to be diuretic and antispasmodic. In Nicaragua, a decoction made of the bark and leaves is used as an abortifacient and to treat malaria, fever and diarrhea. Similarly, in North Central Nigeria, a decoction of the leaves is used as diuretic and for inducing the expulsion of placenta in domestic animals like goats.

The plant has been reported to have antibacterial, ${ }^{9}$ antifungal, ${ }^{10}$ larvicidal, ${ }^{11}$ antioxidant, anticholinesterase $^{12}$ and antiulcer genic ${ }^{13}$ activities. Not much work has been done on the identification of the compounds responsible for these reported activities. Using GC-MS, we aimed to identify the phytochemicals present in the $\mathrm{n}$-hexane fractions of the whole fruit and stem bark as well as determine the total phenolic content, total flavonoid content and 
the DPPH radical scavenging activity of the various extracts of Spondias purpurea.

\section{MATERIALS AND METHODS}

\section{Plant Collection}

The plant samples were collected from Oworo District of Lokoja Local Government Area, Kogi State, and North-Central Nigeria in the month of April 2016. The plant was authenticated at the Forest Herbarium Ibadan (FHI), where a voucher specimen (FHI 110431) was deposited.

\section{Preparation of Plants}

The stem bark was dried in the oven at $60^{\circ} \mathrm{C}$ after which it was pulverized while the whole fruit was dried in the oven at $40^{\circ} \mathrm{C}$. Weighed portions of the various parts were extracted with $80 \%$ methanol for $72 \mathrm{~h}$ with regular stirring. Extracts were filtered and concentrated using rotary evaporator. The extracts were packed in previously weighed glass containers and stored in the refrigerator until use.

\section{Partitioning}

The methanol extracts of the various parts were partitioned into n-hexane, dichloromethane, ethyl acetate and water. The fractions were concentrated in vacuo at $40^{\circ} \mathrm{C}$ and subsequently used for the various test.

\section{Determination of Total Phenol Content (TPC)}

The Folin-Ciocalteu's phenol reagent method of determining the total phenolic content. ${ }^{14}$ To a mixture of $0.1 \mathrm{ml}$ of sample and $0.9 \mathrm{ml}$ of water was added $0.2 \mathrm{ml}$ of Folin-Ciocalteu's phenol reagent and the resulting mixture voltexed. After $5 \mathrm{~min}$ of standing, $1.0 \mathrm{ml}$ of $7 \%$ (w/w) $\mathrm{Na}_{2} \mathrm{CO}_{3}$ solution was added and the solution was then made up to $2.5 \mathrm{ml}$ before incubation for $90 \mathrm{~min}$ at room temperature. The absorbance against a negative control containing $1 \mathrm{ml}$ of water in place of the sample was then taken at $750 \mathrm{~nm}$. The standard used was the Gallic acid at 0.1, 0.08, 0.06, $0.04,0.02 \mathrm{mg} / \mathrm{ml}$ in order to determine Gallic acid Equivalent (GAE) of sample, after preparing a calibration curve.-

$$
\mathrm{X}=\mathrm{q}^{*} \frac{\mathrm{V}}{\mathrm{w}}
$$

$\mathrm{X}=$ Total content of flavonoid compound equivalent in Gallic acid.

$\mathrm{q}=$ concentration of quercetin established from the standard curve.

$\mathrm{V}=$ volume of extract $(\mathrm{ml})$.

$\mathrm{w}=$ weight of the crude methanol extract obtained.

\section{Determination of Total Flavonoid Content (TFC)}

This was carried out based on the aluminum chloride colorimetric assay method. ${ }^{15}$ To $0.1 \mathrm{ml}$ of extract/standard was added $0.4 \mathrm{ml}$ of distilled water. This was followed by $0.1 \mathrm{ml}$ of $5 \%$ sodium nitrite. After $5 \mathrm{~min}$, $0.1 \mathrm{ml}$ of $10 \%$ Aluminum Chloride and $0.2 \mathrm{ml}$ of sodium hydroxide was added and the volume was made up to $2.5 \mathrm{ml}$ with distilled water. The absorbance was measured at $510 \mathrm{~nm}$ against the blank. Standard quercetin with varying concentration $0.1,0.2,0.3,0.4$ and $0.5 \mathrm{mg} / \mathrm{ml}$ was used as standard in comparison to the sample extract. The total flavonoid content of the plant, expressed as mg quercetin equivalents per gram of the plant extract is calculated as:

$$
\mathrm{X}=\mathrm{q}^{*} \frac{\mathrm{V}}{\mathrm{w}}
$$

$\mathrm{X}=$ Total content of flavonoid compound equivalent in quercetin.

$\mathrm{q}=$ concentration of quercetin established from the standard curve.

$\mathrm{V}=$ volume of extract $(\mathrm{ml})$.

$\mathrm{w}=$ weight of the crude methanol extract obtained.

\section{DPPH radical scavenging assay}

The radical scavenging ability of the various extracts was determined using the stable radical DPPH (2,2-diphenyl-1-picrylhydrazyl hydrate). ${ }^{16}$ To $1 \mathrm{ml}$ of different concentrations of the samples or standard (vitamin C) in a test tube was added $1 \mathrm{ml}$ of $0.3 \mathrm{mM} \mathrm{DPPH}$ in methanol. The mixture was mixed and incubated in the dark for $30 \mathrm{~min}$ after which the absorbance was read at $517 \mathrm{~nm}$ against a DPPH blank containing only $1 \mathrm{ml}$ methanol in place of the extract.

The percent of inhibition was calculated using the following formula:

$$
1 \%=\frac{\mathrm{A}_{\text {blank }}-\mathrm{A}_{\text {sample }}}{\mathrm{A}_{\text {sample }}} \times 100
$$

Where $A_{\text {blank }}$ is the absorbance of the control reaction (containing all reagents except the test compound), and $\mathrm{A}_{\text {sample }}$ is the absorbance of the test compound. The concentration of sample providing $50 \%$ inhibition $\left(\mathrm{IC}_{50}\right)$ was calculated from the graph of percentage inhibition against concentration of extract.

\section{Gas Chromatography-Mass Spectrometry (GC-MS) Analysis}

The $\mathrm{n}$-hexane fractions of the whole fruit and stem bark were subjected to GC/MS analysis on an Agilent 5975C mass spectrometer coupled with model 7890A gas chromatograph under the following conditions: HP5MS column, $30 \mathrm{~m} \times 0.32 \mathrm{~mm}$ (internal diameter) and thickness $0.25 \mu \mathrm{m}$ with helium $(99.9999 \%$ purity, flow rate $=1.4963 \mathrm{~mL} / \mathrm{min}$; average velocity $=45.618 \mathrm{~cm} / \mathrm{s}$ ) as carrier gas. $1 \mu \mathrm{L}$ of $0.2 \mathrm{~g} / \mathrm{mL}$ fraction was injected. A 7683B injector type was used in a split less mode; GC temperature program, $80-290^{\circ} \mathrm{C}$ at $10^{\circ} \mathrm{C} / \mathrm{min}(5 \mathrm{~min}$. initial hold); Total run time of $28 \mathrm{~min}$. The mass spectra were recorded in electron ionization (EI) mode at $70 \mathrm{eV}$.

Identification of phytochemicals and interpretation of mass spectrum GC-MS was conducted by comparing retention time and mass spectra with those of authentic compounds using the National Institute of Standards and Technology (NIST) 14 Mass Spectral Library, Washington, DC, USA. The name, molecular weight, retention time and structure of the components of the test materials were ascertained and reported.

\section{Statistical analysis}

All determinations were done in triplicate, and the results reported as mean \pm standard error of mean (S.E.M.). The calculation of $\mathrm{IC}_{50}$ values was done using Microsoft Excel 2010.

\section{RESULTS}

The total Phenolic and Total Flavonoid content of the Whole fruit and Stem bark extracts and partitioned fractions are as reported in Table 1 while Table 2 showed the DPPH Free Radical Scavenging Activities of the extracts.

The chemical analysis was also carried out. Table 3 and 4 shows the GC-MS analysis and mass spectral data of the n-hexane fraction of the whole fruit of the extracts showing molecular name, molecular weight, molecular formula, retention time, percentage content, and peak areas.

\section{DISCUSSIONS}

The total phenolic and total flavonoid content of the extracts and fractions of $S$. purpurae was evaluated. The results for the whole fruit and stem bark extracts and partitioned fractions are as presented in Table 1 below. Phenols are important class of secondary metabolite with good radical scavenging capability which they possess mainly due to the $\mathrm{OH}$ present in their structure. The Result of TPC is as shown in Table 1. The result 
Table 1: Total Phenolic and Total Flavonoid content of the Whole fruit and Stem bark extracts and partitioned fractions.

\begin{tabular}{rcc}
\hline Partitioned fractions & $\begin{array}{c}\text { Total Phenolic } \\
(\mathrm{mg} \mathrm{GAE} / \mathrm{g})\end{array}$ & $\begin{array}{c}\text { Total Flavonoid } \\
(\mathrm{mg} \mathrm{QE} / \mathrm{g})\end{array}$ \\
\hline Aqu & Whole fruit extract $9.09+0.40$ & $3.83+0.10$ \\
EtoAc & $11.75 \pm 0.91$ & $1.83 \pm 0.63$ \\
DCM & $18.65 \pm 0.8$ & $3.99 \pm 0.40$ \\
n-Hex & $19.19 \pm 1.36$ & $2.72 \pm 0.49$ \\
& $8.317 \pm 0.25$ & $3.15 \pm 0.27$ \\
Aqu & Stem bark extract $29.81+1.187 .30+0.08$ \\
EtoAc & $26.51 \pm 2.49$ & $3.35 \pm 0.25$ \\
DCM & $46.88 \pm 1.23$ & $14.97 \pm 4.60$ \\
n-Hexane & $18.53 \pm 0.77$ & $5.89 \pm 1.58$ \\
& $4.029 \pm 0.092$ & $7.42 \pm 1.63$
\end{tabular}

Key: Aqu: Aqueous, EtoAc: Ethyl acetate, DCM: Dichloromethane, n-Hex: n-Hexane

TPC was calculated as the total phenolic content equivalent of gallic acid using the equation of the curve $y=4.1503 x-0.0242 R^{2}=0.9841$. The Total Flavonoid content was likewise calculated as the total Flavonoid equivalent of Quercetin using the equation of the curve, $y=1.035 x+0.0624, R^{2}=0.9661$. Values are presented as $\mathrm{mg} \mathrm{GAE} / \mathrm{g} \pm$ S.E.M and $\mathrm{mg} \mathrm{QE} / \mathrm{g} \pm$ S.E.M respectively.

Table 2: DPPH Free Radical Scavenging Activities.

\begin{tabular}{cc}
\hline Plant parts & $\mathrm{IC}_{50}(\mu \mathrm{g} / \mathrm{mL})$ \\
\hline Whole fruit & $280.0 \pm 7.1$ \\
Stem bark & $8.3 \pm 1.51$ \\
Ascorbic Acid & $11.5 \pm 0.3$
\end{tabular}

$\mathrm{IC}_{50}$ results are expressed as $\mu \mathrm{g} / \mathrm{mL} \pm \mathrm{SEM}$ (Standard Error of Mean). showed the whole fruit and the stem bark contain $9.01 \pm 0.4$ and $29.81 \pm$ $1.18 \mathrm{mg} \mathrm{GAE} / \mathrm{g}$ of phenol respectively. Different TPC values have been reported for various species of Spondias. Values of $55.0 \mathrm{mg}$ and 44.6 $\mathrm{mg}$ of GAE/100 $\mathrm{g}$ for $S$. purpurea and $S$. tuberosa fruit pulp respectively have been reported. ${ }^{17} \mathrm{~A}$ higher value of $112.2 \pm 13.2,254.7 \pm 42.1$ and $13.5 \pm 1.3 \mathrm{mg} \mathrm{GAE} / \mathrm{g}$ for the peel kernel and pulp of $S$. purpurea has also been reported. ${ }^{12}$ S. mombin was reported to contain $260.21 \pm 11.89 \mathrm{mg}$ GAE/100g in the fruit pulp, ${ }^{18} 573.32 \mathrm{mg}$ of GAE/100g in the kernel, ${ }^{19}$ and $213.50 \pm 1.25 \mathrm{mg} \mathrm{GAE} / \mathrm{g}$ polyphenol content in the leaves. ${ }^{20}$ It is important to note that the Folin-Ciocalteu reagent assay is not specific for phenolic compounds since it can also be reduced by many nonphenolic compounds such as ascorbic acid. ${ }^{12}$ The result for the TPC of

Table 3: GC-MS analysis and mass spectral data of the $n$-hexane fraction of the whole fruit of Spondias purpurea showing molecular name, molecular weight, molecular formula, retention time, percentage content, and peak areas.

\begin{tabular}{|c|c|c|c|c|c|}
\hline $\begin{array}{l}\text { Serial } \\
\text { No. }\end{array}$ & Molecular Name & $\begin{array}{c}\text { Molecular } \\
\text { weight } \\
\text { (g/mol) }\end{array}$ & $\begin{array}{c}\text { Molecular } \\
\text { Formula }\end{array}$ & $\begin{array}{l}\text { Retention } \\
\text { Time (min) }\end{array}$ & $\begin{array}{c}\text { Peak } \\
\text { Area } \\
\text { percent }\end{array}$ \\
\hline 1 & Pentadecanoicacid ${ }^{\mathrm{a}}$ & 242.403 & $\mathrm{C}_{15} \mathrm{H}_{30} \mathrm{O}_{2}$ & 18.725 & 3.85 \\
\hline 2 & n-hexadecanoicacid ${ }^{\mathrm{b}}$ & 256.43 & $\mathrm{C}_{16} \mathrm{H}_{32} \mathrm{O}_{2}$ & 19.355 & 7.07 \\
\hline 3 & $\begin{array}{c}\text { 9,12-cctadecadienoic } \\
\text { acid }^{c}\end{array}$ & 280.452 & $\mathrm{C}_{18} \mathrm{H}_{32} \mathrm{O}_{2}$ & 20.819 & 2.98 \\
\hline 4 & 10-octadecenoic acid & 282.468 & $\mathrm{C}_{18} \mathrm{H}_{34} \mathrm{O}_{2}$ & 20.894 & 2.99 \\
\hline 5 & Methyl stearate ${ }^{\mathrm{d}}$ & 298.511 & $\mathrm{C}_{19} \mathrm{H}_{38} \mathrm{O}$ & 21.168 & 1.17 \\
\hline 6 & 9,17 -octadecadienal ${ }^{\mathrm{h}}$ & 264.446 & $\mathrm{C}_{18} \mathrm{H}_{32} \mathrm{O}$ & 21.443 & 5.43 \\
\hline 7 & $\begin{array}{l}\text { 3-((4Z,7Z)-heptadeca- } \\
\text { 4,7-dien-1-yl) phenol }\end{array}$ & 328.5313 & $\mathrm{C}_{23} \mathrm{H}_{36} \mathrm{O}$ & 21.689 & 12.00 \\
\hline 8 & $\begin{array}{l}\text { (Z)-3-(heptadec-10- } \\
\text { en-1-yl) phenol }\end{array}$ & 330.556 & $\mathrm{C}_{23} \mathrm{H}_{38} \mathrm{O}$ & 22.336 & 11.76 \\
\hline 9 & Phenol, 3-pentadecyl $l^{\mathrm{f}}$ & 304.510 & $\mathrm{C}_{21} \mathrm{H}_{36} \mathrm{O}$ & 22.868 & 2.60 \\
\hline
\end{tabular}

Table 4: GC-MS analysis and mass spectral data of the $n$-hexane fraction of the stem bark of Spondias purpurea showing molecular name, molecular weight, molecular formula, retention time, percentage content, and peak areas.

\begin{tabular}{|c|c|c|c|c|c|}
\hline Peak Compound & Molecular formular & Molecular weight & Molecular Formula & Retention Time (min) & Peak Area percent \\
\hline 1 & Pentadecanoicacid $^{a}$ & 242.403 & $\mathrm{C}_{15} \mathrm{H}_{30} \mathrm{O}_{2}$ & 18.742 & 8.30 \\
\hline 2 & n-hexadecanoicacid ${ }^{\mathrm{b}}$ & 256.43 & $\mathrm{C}_{16} \mathrm{H}_{32} \mathrm{O}_{2}$ & 19.383 & 15.24 \\
\hline 3 & Ethyl 5-methylhexanoate & 158.238 & $\mathrm{C}_{9} \mathrm{H}_{18} \mathrm{O}_{2}$ & 19.583 & 0.82 \\
\hline 4 & 9,12 -octadecadienoic acid ${ }^{c}$ & 280.452 & $\mathrm{C}_{18} \mathrm{H}_{32} \mathrm{O}_{2}$ & 20.836 & 4.95 \\
\hline 5 & trans-13-octadecenoic acid & 282.468 & $\mathrm{C}_{18} \mathrm{H}_{34} \mathrm{O}_{2}$ & 20.934 & 12.61 \\
\hline 6 & 13-octadecenoic acid & 282.468 & $\mathrm{C}_{18} \mathrm{H}_{34} \mathrm{O}_{2}$ & 21.077 & 0.96 \\
\hline 7 & Methyl stearate & 298.511 & $\mathrm{C}_{19} \mathrm{H}_{38} \mathrm{O}$ & 21.185 & 1.45 \\
\hline 8 & 9,17 -octadecadienal ${ }^{\mathrm{h}}$ & 264.446 & $\mathrm{C}_{18} \mathrm{H}_{32} \mathrm{O}$ & 21.552 & 20.51 \\
\hline 9 & 9,12,15-octadecatrienoic acidg & 278.436 & $\mathrm{C}_{18} \mathrm{H}_{30} \mathrm{O}_{2}$ & 21.695 & 3.17 \\
\hline 10 & 3-pentadecyl-phenol & & & 23.091 & 1.48 \\
\hline 11 & Methyl 13-eicosenoate & 324.549 & $\mathrm{C}_{21} \mathrm{H}_{40} \mathrm{O}_{2}$ & 23.531 & 2.27 \\
\hline 12 & (Z)-3-(pentadec-8-en-1-yl)phenol & & & 26.095 & 4.59 \\
\hline 13 & Phenol, 3-tridecyl- & 276.464 & $\mathrm{C}_{19} \mathrm{H}_{32} \mathrm{O}$ & 26.535 & 12.92 \\
\hline
\end{tabular}




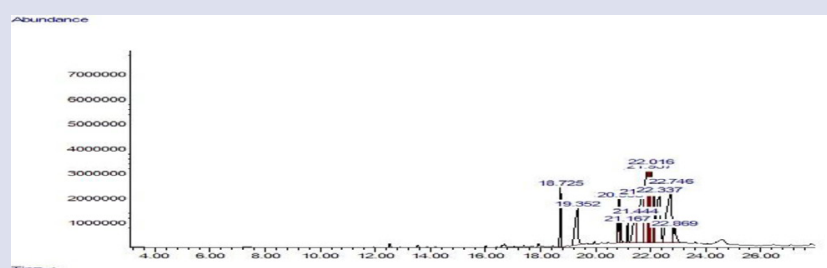

Figure 1: Chromatogram for the Gas Chromatography of $n$-hexane fraction of the whole fruit.

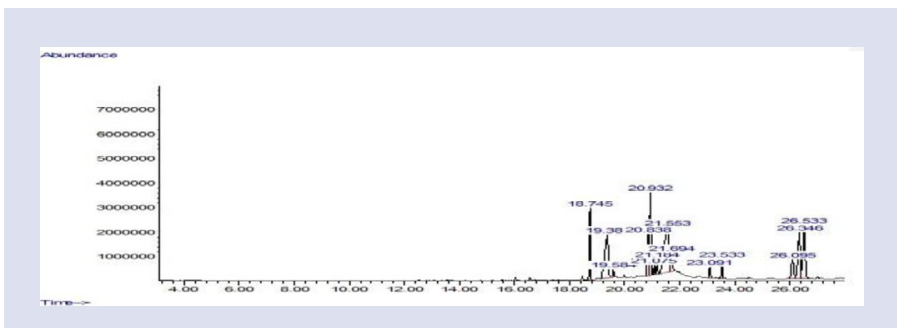

Figure 2: Chromatogram for the Gas Chromatography of $\mathrm{n}$-hexane fraction of the stem bark.

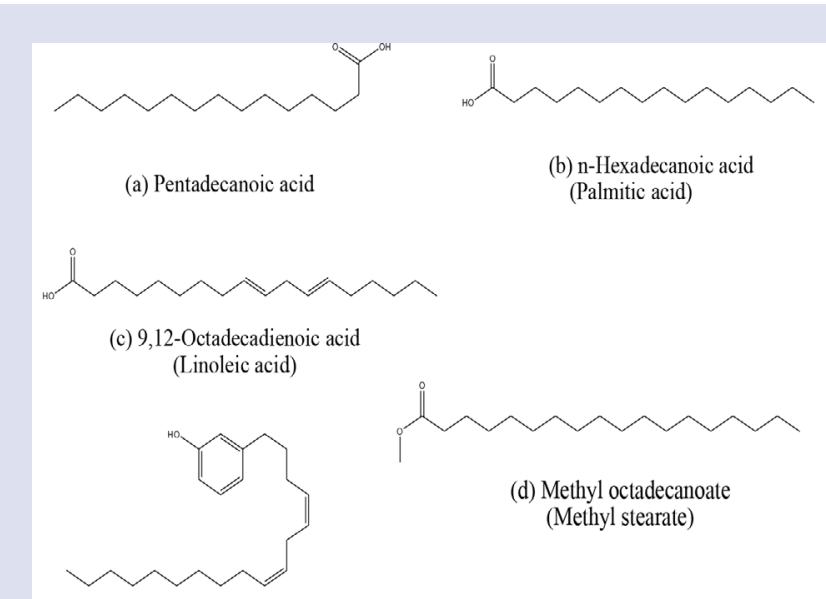

(e) 3-((4Z,7Z)-Heptadeca-4,7-dien-1-yl) phenol

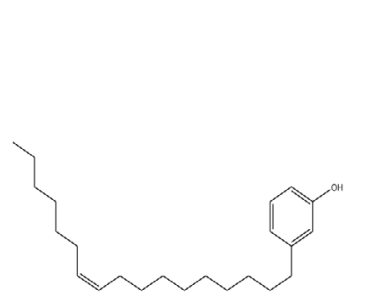

(e) (Z)-3-(Heptadec-10-en-1-yl) phenol

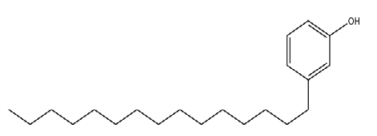

(f) Phenol, 3-pentadecyl-

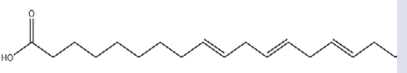

(g) 9,12,15-Octadecatrienoic acid (a-Linolenic Acid)

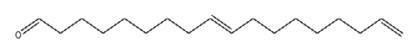

(h) 9,17-Octadecadienal

Figure 3: Structures of some compounds identified in Spondias purpurea through CG-MS. the fractions showed the ethyl acetate fractions for both the whole fruit and stem bark as having the highest amount of $18.65407 \pm 0.8 \mathrm{mg} \mathrm{GAE} / \mathrm{g}$ and $46.88 \pm 1.23 \mathrm{mg} \mathrm{GAE} / \mathrm{g}$ respectively, higher than those of the aqueous, dichloromethane and $n$-hexane fractions. Flavonoids are a group of phenolic secondary metabolites with the basic structural skeleton $\mathrm{C}_{6} \mathrm{C}_{5}-\mathrm{C}_{6}$, and known to have several health benefits due to their good antioxidant activities. The total flavonoid content of the various extracts of the plant was estimated as the total flavonoid equivalent of Quercetin (Table 1). In a similar trend to that of TPC, the TFC results showed the stem bark to contained the highest flavonoids content with a value of $7.39 \pm 0.08 \mathrm{mg}$ QE/g while the ethyl acetate fractions also had the highest value of $14.97 \pm 4.60$.

The DPPH free Radical Scavenging Activities (RSA) of the extracts and fractions were also determined. The result of the 2, 2-diphenyl-1-picrylhydrazyl (DPPH) free radical scavenging activities of the extracts and fractions are as presented in Table 2. Oxidative stress has been linked to several chronic diseases such as Alzheimer's disease, cancer, hypertension, atherosclerosis, diabetics, rheumatoid arthritis etc and natural antioxidant are now being considered as capable of preventing or ameliorating these diseases. ${ }^{21}$ The result of the DPPH free RSA assay revealed that all the parts of the plant have some antioxidant property (Table 2) with the stem bark being the highest with $\mathrm{IC}_{50}$ of $8.3 \pm 1.5 \mu \mathrm{g} / \mathrm{mL}$, a value actually lower than that of the standard drug ascorbic acid $\left(\mathrm{IC}_{50}\right.$ of 11.5 $\pm 0.3 \mu \mathrm{g} / \mathrm{mL}$ ). However, the whole fruit showed the low antioxidant capacity with an $\mathrm{IC}_{50}$ of $280.0 \pm 7.1 \mu \mathrm{g} / \mathrm{mL} \mathrm{An} \mathrm{IC}_{50}$ value of $36.37 \mu \mathrm{g} / \mathrm{mL}$ and $173.37 \mu \mathrm{g} / \mathrm{mL}$ was reported for the seeds of $S$. purpurea and S. tuberosa respectively. ${ }^{12}$

The phytoconstituents in the fractions of $S$. purpurae were analysed by GC. MS with the chromatograms as reported in Figures 1 and 2. Many compounds were identified and their chemical names, formula, molecular weight and peak areas (\%) are listed as in Tables 3 and 4 with representative structures Figure 3. Nine compounds including 9, 17-octadecadienal (5.43\%), 3-((4Z, 7Z)-heptadeca-4,7-dien-1-yl) phenol (12\%), (Z)-3(heptadec-10-en-1-yl) phenol (11.76\%), n-hexadecanoic acid (7.07\%) were identified in the $\mathrm{n}$-hexane fractions of the whole fruit. Similarly, 13 compounds were detected in the stem bark n-Hexane fraction. These include 9, 17-octadecadienal(20.51\%), trans-13-octadecenoic acid (12.61\%), pentadecanoic acid (8.3\%), n-hexadecanoic acid (15.24\%). These compounds are long chain fatty acid esters, alkanal and phenols having between 9-23 carbons, generally longer and of higher molecular weight than compounds such as hexanal and 2-hexen-1-ol detected in the volatile oil of the fruit. ${ }^{5}$ Reported biological activities for the identified compounds showed n-hexadecanoic (palmitic acid) acid and pentadecanoic to possess antioxidants property and cyclooxygenase. ${ }^{23-25}$ Also, linoleic and linolenic acid were reported to possess anti-inflammatory, insectifuge, hypocholesterolemic, cancer preventive, hepatoprotective and antihistaminic properties. ${ }^{26-28}$ The essential fatty acid, 9,12,15-octadecatrienoic acid ( $\alpha$-linoleic acid) is reported to have neuroprotective property against soma-induced neuropathology. ${ }^{29}$ Perez-Pinzon and $\operatorname{Lin}^{30}$ 2017 reported that polyunsaturated or saturated fatty acids such as palmitic acid methyl ester and $\alpha$-linolenic acid are capable of offering neuroprotection after ischemia.

\section{CONCLUSION}

Based on these results, the high phenolic and flavonoid contents of the stem bark extract could be responsible for its greater antioxidant activity as reflected in the DPPH free radical scavenging effect. ${ }^{31}$ Moreover, previous researchers have reported that phenolic and fatty acids possesses high antioxidant activity. ${ }^{25,32-33}$ 


\section{ACKNOWLEDGEMENT}

The authors acknowledge the contributions of the National Institute of Technology in the identification of the chemical constituents of the plant.

\section{CONFLICT OF INTEREST}

Authors declare no conflict of interest.

\section{ABBREVIATIONS}

DPPH: 2, 2-diphenyl-1-picrylhydrazyl; GAE: Gallic acid Equivalent; GC-MS: Gas Chromatography-Mass Spectroscopy; NIST: National Institute of Standards and Technology; TFC: Total Flavonoid Content; TPC: Total Phenol Content.

\section{REFERENCES}

1. Ekor M. The growing use of herbal medicines: issues relating to adverse reactions and challenges in monitoring safety. Front Pharmacol. 2013;4:177.

2. Cowan MM. Plant products as antimicrobial agents. Clin Microbiol Rev. 1999; 12(4):564-82.

3. Banjo AD, Lawal OA, Aina SA. Insects associated with some medicinal plants in South-Western Nigeria. World J Zool. 2006;1(1):40-3.

4. Miller A, Schaal B. Domestication of a Mesoamerican cultivated fruit tree, Spondias purpurea. Proc Natl Acad Sci U S A. 2005;102(36):12801-6.

5. Bicas JL, Molina G, Dionísio AP, Barros FF, Wagner R, Maróstica Jr MR, et al. Volatile constituents of exotic fruits from Brazil. Food Res Int. 2011;44(7):1843-55.

6. Mitchell JD, Daly DC, Randrianasolo A. The first report of Spondias native to Madagascar: Spondias tefyi, sp nov(Anacardiaceae). Brittonia. 2012;64(3):263-7.

7. Rosas-Piñón Y, Mejía A, Díaz-Ruiz G, Aguilar MI, Sánchez-Nieto S, Rivero-Cruz JF. Ethnobotanical survey and antibacterial activity of plants used in the Altiplane region of Mexico for the treatment of oral cavity infections. J Ethnopharmacol. 2012;141(3):860-5

8. Neto EM, Peroni N, De Albuquerque UP. Traditional knowledge and management of Umbu (Spondias tuberosa, Anacardiaceae): An endemic species from the semi-arid region of Northeastern Brazil. Econ Bot. 2010;64(1):11-21.

9. Miranda-Cruz E, Espinosa-Moreno J, Centurion-Hidalgo D, Velázquez-Martínez JR, Alor-Chávez $\mathrm{M}$ de J. Actividad antimicrobiana de extractos de Psidium friedrichsthalianum L, Pterocarpus hayesii L, Tynanthus guatemalensis L. y Spondias purpurea L. Boletín Latinoam y del Caribe Plantas Med y Aromáticas. 2012;11(4).

10. Pizana CG, Necha LL, Gomez MY. Evaluation of the fungicidal activity of leaves powders and extracts of fifteen mexican plants against Fusarium oxysporum $\mathrm{f}$. sp. gadioli (Massey) snyder and hansen. Plant Pathol J. 2010.

11. Lima MA, De Oliveira FF, Gomes GA, Lavor PL, Santiago GM, Nagao-Dias AT, et al. Evaluation of larvicidal activity of the essential oils of plants species from Brazil against Aedes aegypti (Diptera: Culicidae). African J Biotechnol. 2011; 10(55):11716

12. Omena CM, Valentim IB, Guedes G da S, Rabelo LA, Mano CM, Bechara EJ, et al. Antioxidant, anti-acetylcholinesterase and cytotoxic activities of ethanol extracts of peel, pulp and seeds of exotic Brazilian fruits: Antioxidant, anti-acetylcholinesterase and cytotoxic activities in fruits. Food Res Int. 2012;49(1):334-44.

13. Dantas AM. Avaliação da toxicidade e atividade antiulcerogênica das folhas de
Spondias purpurea L. 2012.

14. Arogba SS. Phenolics, antiradical assay and cytotoxicity of processed mango (Mangifera indica) and bush mango (Irvingia gabonensis) kernels. Niger Food J. 2014;32(1):62-72

15. Miliauskas G, Venskutonis PR, Van Beek TA. Screening of radical scavenging activity of some medicinal and aromatic plant extracts. Food Chem. 2004; 85(2):231-7.

16. Brand-Williams W, Cuvelier ME, Berset C. Use of a free radical method to evaluate antioxidant activity. LWT-Food Sci Technol. 1995;28(1):25-30.

17. Almeida MM, De Sousa PH, Arriaga ÂM, Do Prado GM, De Carvalho Magalhães CE, Maia GA, et al. Bioactive compounds and antioxidant activity of fresh exotic fruits from northeastern Brazil. Food Res Int. 2011:44(7):2155-9.

18. Tiburski JH, Rosenthal A, Deliza R, De Oliveira Godoy RL, Pacheco S. Nutritional properties of yellow mombin (Spondias mombin L.) pulp Food Res Int. 2011;44(7):2326-31.

19. Esua OJ, Makinde OO, Arueya GL, Chin NL. Antioxidant potential, phytochemical and nutrient compositions of Nigerian hog plum (Spondias mombin) seed kernel as a new food source. Int Food Res J. 2016;23.

20. Omoregie ES, Oikeh El. Comparative studies on the phytochemical composition, phenolic content and antioxidant activities of methanol leaf extracts of Spondias mombin and Polyathia longifolia. Jordan J Biol Sci. 2015;147(3427):1-5.

21. Uttara B, Singh AV, Zamboni P, Mahajan RT. Oxidative stress and neurodegener ative diseases: A review of upstream and downstream antioxidant therapeutic options. Curr Neuropharmacol. 2009;7(1):65-74.

22. Chen $X$, Guo $C$, Kong J. Oxidative stress in neurodegenerative diseases. Neural Regen Res. 2012;7(5):376.

23. Benkendorff K, Davis AR, Rogers CN, Bremner JB. Free fatty acids and sterols in the benthic spawn of aquatic molluscs, and their associated antimicrobial properties. J Exp Mar Bio Ecol. 2005;316(1):29-44.

24. Henry GE, Momin RA, Nair MG, Dewitt DL. Antioxidant and cyclooxygenase activities of fatty acids found in food. J Agric Food Chem. 2002;50(8):2231-4

25. Suhaj M. Spice antioxidants isolation and their antiradical activity: A review. J food Compos Anal. 2006;19(6-7):531-7.

26. Tapiero H, Ba GN, Couvreur P, Tew KD. Polyunsaturated fatty acids (PUFA) and eicosanoids in human health and pathologies. Biomed Pharmacother. 2002;56(5):215-22.

27. Pinna A, Piccinini P, Carta F. Effect of oral linoleic and $\gamma$-linolenic acid on meibomian gland dysfunction. Cornea. 2007;26(3):260-4.

28. Goldberg RJ, Katz J. A meta-analysis of the analgesic effects of omega-3 polyunsaturated fatty acid supplementation for inflammatory joint pain. Pain. 2007;129(1-2):210-23

29. Pan H, Hu X, Jacobowitz DM, Chen C, McDonough J, Van Shura K, et al. Alphalinolenic acid is a potent neuroprotective agent against soman-induced neuropathology. Neurotoxicology. 2012;33(5):1219-29.

30. Lin HW, Perez-Pinzon M. The role of fatty acids in the regulation of cerebra vascular function and neuroprotection in ischemia. CNS Neurol Disord Targets (Formerly Curr Drug Targets-CNS Neurol Disord. 2013;12(3):316-24.

31. Proestos C, Chorianopoulos N, Nychas GJ, Komaitis M. RP-HPLC analysis of the phenolic compounds of plant extracts, Investigation of their antioxidan capacity and antimicrobial activity. J Agric Food Chem. 2005;53(4):1190-5.

32. Zhang HJ, Guo YM, Tian YD, Yuan JM. Dietary conjugated linoleic acid improves antioxidant capacity in broiler chicks. Br Poult Sci. 2008;49(2):213-21.

33. Kumar PP, Kumaravel S, Lalitha C. Screening of antioxidant activity, total phenolics and GC-MS study of Vitex negundo. African J Biochem Res. 2010;4(7):191-5.

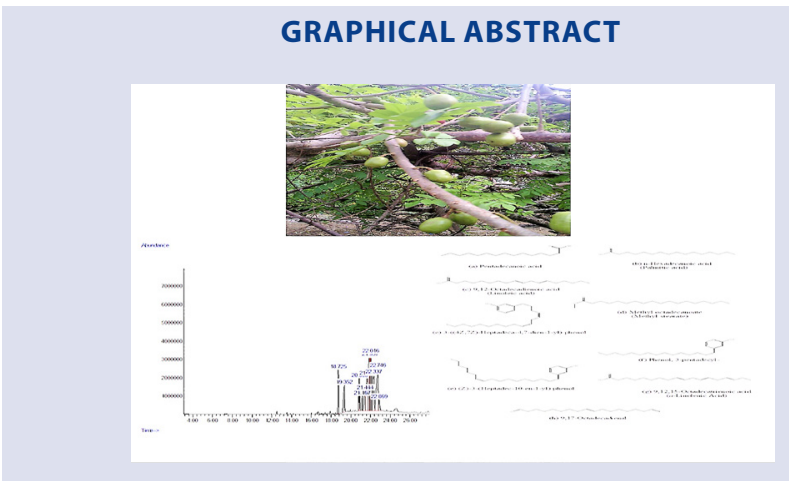

\section{SUMMARY}

Spondias purpurae possesses antioxidant properties that can be justified by the chemical compounds identified in its various fractions.

\section{ABOUT AUTHORS}

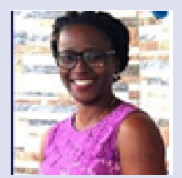

Dr. Taiwo O. Elufioye is a senior lecturer in the Department of Pharmacognosy, Faculty of Pharmacy, University of Ibadan, Nigeria

Cite this article: Elufioye TO, Berida TI. GC-MS Analysis and Antioxidant Activity of Spondias purpurea L (Anacardiaceae). Pharmacog J. 2018;10(5):941-5 